RETRACTION NOTE

\title{
Retraction Note: Dioscin induces prostate cancer cell apoptosis through activation of estrogen receptor- $\beta$
}

Xufeng Tao, Lina Xu, Lianhong Yin, Xu Han, Yan Qi, Youwei Xu, Shasha Song, Yanyan Zhao and Jinyong Peng

(c) The Author(s) 2021

Cell Death and Disease (2021)12:800; https://doi.org/10.1038/s41419-021-04083-y

Retraction Note: Cell Death \& Disease https://doi.org/10.1038/ cddis.2017.391, published online 10 August 2017

The Editors-in-Chief have retracted this article because concerns have been raised regarding some of the figures. An investigation by the College of Pharmacy Dalian Medical University has established that during the course of revision, the result of the transwell migration assay in Fig. $5 c$ was provided by mistake due to file placement confusion. In Fig. 7c, the graph of HE staining of ERß-siRNA+Dioscin group was incorrectly uploaded and was different from our original data. While the institutional investigation has not found evidence of misconduct, the Editors-in-Chief have found that due to the errors the findings are no longer reliable. The authors all agree with this retraction.

\begin{abstract}
Open Access This article is licensed under a Creative Commons Attribution 4.0 International License, which permits use, sharing, adaptation, distribution and reproduction in any medium or format, as long as you give appropriate credit to the original author(s) and the source, provide a link to the Creative Commons license, and indicate if changes were made. The images or other third party material in this article are included in the article's Creative Commons license, unless indicated otherwise in a credit line to the material. If material is not included in the article's Creative Commons license and your intended use is not permitted by statutory regulation or exceeds the permitted use, you will need to obtain permission directly from the copyright holder. To view a copy of this license, visit http://creativecommons. org/licenses/by/4.0/.
\end{abstract}

(c) The Author(s) 2021 